Article

\title{
Perception of Nature's Contributions to People in Rural Communities in the Eastern Amazon
}

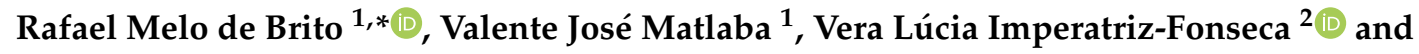 \\ Tereza Cristina Giannini ${ }^{1}$ (D) \\ 1 Instituto Tecnológico Vale, Rua Boaventura da Silva, 955, Belém 66055-900, Brazil; \\ valente.matlaba@itv.org (V.J.M.); tereza.giannini@itv.org (T.C.G.) \\ 2 Instituto de Biociências, Universidade de S. Paulo, CEP 05508-090 São Paulo, Brazil; vlifonse@ib.usp.br \\ * Correspondence: britodemelorafael@gmail.com; Tel.: +55-91-3213-5521
}

Received: 3 July 2020; Accepted: 1 September 2020; Published: 17 September 2020

\begin{abstract}
Nature's contributions to people (NCP) are increasingly being considered in decisions by policy-makers because of their relevance to the well-being of people. Learning the value of nature from the perception of communities can help to define priorities and to guide the development of public policies for environmental conservation. The objective of this study was to analyze the perception of the importance, benefits, and problems of NCP among residents of five rural communities, and their opinion about the protected areas of the municipality, considering their socioeconomic characteristics. The method consisted of conducting questionnaire-based, semi-structured, face-to-face interviews with a sample of 214 randomly selected households in five rural communities of Parauapebas (Pará, Eastern Amazon). We used appropriate statistical tests for data analysis. The main results show that the communities were highly homogeneous and that $52 \%$ of the households had low income (below a minimum wage of USD 250). A high proportion of respondents gave the highest importance to all categories of NCP (2/3 of respondents for material, $3 / 4$ for non-material, and $4 / 5$ for regulating NCP). The most commonly mentioned benefits of NCP referred to subsistence or livelihood and quality of life ( $40 \%$ of total mentions). Environmental degradation problems were the most cited (38\% of total mentions). Almost all respondents stated that they had a positive opinion about the protected areas of the municipality, despite underusing them. This study is relevant because it analyses, for the first time, the perceptions of NCP among residents of rural communities in the Eastern Amazon, an essential aspect for decision-and public policy-making.
\end{abstract}

Keywords: valuation; biodiversity; ecosystem services; Amazon biome; Carajás National Forest

\section{Introduction}

Protected areas of the tropical forest, directly and indirectly, contribute to the quality of life of human communities. Carbon sequestration and storage, biodiversity maintenance, rainfall generation, and drought risk reduction are examples of these contributions [1]. Although, currently, a large expanse of the Amazon Forest is under protection, the rural development model implemented decades ago in the Brazilian Amazon has proved to be unsustainable, due to the replacement of natural areas by unprofitable pastures [2], which highlights the importance of protected areas and to shape a new model based on the sustainable use of nature. There are several pressures on protected areas (PAs) in the Amazon, from the agribusiness lobby, logging interests, or illegal mining activities, all of which influence decision-makers [3]. Rolling back various environmental protections, passing laws disregarding scientific knowledge and decreasing the power of socioenvironmental protection state agencies and corporations [4] may be accelerating the degradation of ecosystems in this biome and, 
thus, compromising, even more, the quality of life of rural communities that depend more directly on the contributions provided by nature [5].

The Millennium Ecosystem Assessment [5] defines these contributions as ecosystem services (ES) and classifies them into four different groups: (1) provisioning services, related to products (materials) extracted from the ecosystem (food, wood, and water, among others); (2) regulating services, concerning processes regulated by ecosystems (climate regulation, air quality regulation, disease control, water purification, and pollination, among others); (3) cultural services, referring to non-material benefits (aesthetic, educational, and recreational values, among others); and (4) supporting services, which provide indirect benefits and are necessary for the provision of other services (water and nutrient cycling, soil formation, and photosynthesis, among others). Likewise, Díaz et al. [6] divide nature's contributions to people (NCP) into three overlapping groups: (1) material, defined as substances, objects, and other natural elements; (2) regulating, representing functional and structural aspects which indirectly affect people's lives; and, (3) non-material, which are the effects of nature on the subjective and psychological aspects that influence both individual and collective quality of life.

Since the late 1990s, the published studies [7-13] have estimated the value and highlighted the importance of those contributions worldwide using a wide range [14] of monetary [10] and non-monetary valuation methods [15]. However, valuation often focusses on a few or a single contribution, presenting low applicability for decision-making [16].

For Foley et al. [17], how society seeks to satisfy its immediate needs by extracting natural resources has led to environmental degradation and to significant changes in the Earth's surface (urban growth, expansion of agricultural areas, and deforestation, among others). Changes in land cover and use reduced the quality of ecosystems and directly limited their ability to provide such contributions [18]. Agricultural areas, for example, are highly dependent on NCP provided by natural ecosystems and generate many other benefits, but if poorly managed, they may also generate disservices such as habitat loss and pollinator's deficit due to pesticide [19]. Policy and decision making that intend to address complex environmental interrelationships must consider local knowledge and social perspectives [20].

According to Martín-López et al. [21], successful local public policies must consider the opinions and preferences of the population. Studies that use perception-based approaches to value NCP demonstrate the importance of this method for conservation policies [15]. Gold (1984) defines perception as a "psychological function that enables individuals to convert sensory stimuli into organised and coherent experience" [22] (p. 5). For Tuan [23], perception is related to "the response of the senses to external stimuli and purposeful activity," and "much of what we perceive has a value for us, for biological survival, and for providing some satisfaction that is rooted in culture". Panquestor and Riguetti [24] (p. 7) conceptualized environmental perception as "the act of perceiving one's environment" and is fundamental for a better understanding of the relationship between society and nature. For these authors, scholars can construct environmental perception to support planning policies. Accordingly, the perception of the environment is related to several factors (cultural, social and economic) which may differently influence the views of people. Various studies highlight the importance of considering perceptions and opinions of people when formulating environmental and conservation policies [24-27]. Scholte et al. [28] emphasize the importance of sociocultural valuation methods with pluralist approaches whereby researchers can better evaluate the local context and translate values into decision-making.

In Brazil, since the late 1980s, studies on perception ranging from the fields of social sciences to biological sciences, including multidisciplinary areas, have been published, focusing primarily on the Southeast and South regions [29]. For example, Dias and Mota [30] analysed the perception of rural communities of the benefits of establishing a protected area near their lands in the Atlantic Forest. De Santana et al. [31] estimated the total economic value (TEV) of the vegetation of open areas in the Southwestern Amazon, according to the perception of the local population. However, despite the growing threat to the Amazon biome and its consequences [32,33], there are almost no studies on the perception of the NCP by rural communities. Understanding how rural communities perceive 
and value NCP may foster and guide decision-making that is in line with the expectations of the local population.

Studies showed that rural communities tend to value NCP, especially concerning water, food production, and air quality $[27,34,35]$ and that the difference in the socioeconomic profile can influence the perception of the importance of such contributions, mainly about income and education, but also age and gender $[27,36,37]$. PAs, on the other hand, tend to be valued for the benefits they provide, but more appropriate use could contribute to poverty reduction in nearby rural communities [38].

The Brazilian Amazon is located in the north of the country and includes seven states, being Pará one of them. Deforestation has intensified since the opening of the Trans-Amazonian Highway (Rodovia Federal Transamazônica; BR-230) in the 1970s, and has resulted in biodiversity loss, reduced water cycling, and increased global warming [3]. The southeast region of Pará, located in the Eastern Amazon, is included in the area known as the Deforestation Arc, and has the most degraded area in the state [39], where the municipality of Parauapebas locates. In the last decade, Parauapebas was among the municipalities with the best socio-economic indexes in the state (GDP per capita, Human Development Index, average monthly salary, the proportion of employed persons) [40] and nowadays, nearly $80 \%$ of its territory is under protection; even so, it presents problems related to basic sanitation and social vulnerabilities in urban and rural communities [40,41].

Although rural communities depend more directly on NCP and are more affected by environmental degradation, we realize that, in the Amazon, socioeconomic information on the rural community level and studies valuing nature contributions based on the opinion of these communities are still lacking. Knowing the opinion about the value of NCP, the possible benefits and problems related to them, and the use and importance of PAs can directly guide environmental planning at the local and regional levels. Furthermore, such a study could suggest other approaches that encourage sustainable use of natural resources and improve the quality of life of residents.

The objective of this study was to analyze the perception of residents of five rural communities in Parauapebas about the importance, benefits, and problems of fifteen NCP, and their opinion about the PAs of the municipality, considering their socioeconomic characteristics. We used the three categories of NCP (material, regulating, and non-material) described by Díaz et al. [6]. The study questions are:

1. What are the socioeconomic characteristics of rural communities of Parauapebas?

2. Do the NCP categories have the same importance value, and do socioeconomic characteristics influence this value?

3. What are the main benefits and problems related to the different NCP categories?

4. What is the importance of the PAs located within the municipality?

We test the following research hypotheses:

1. The rural communities of Parauapebas are socioeconomically vulnerable.

2. The communities place a high value on all NCP categories, especially material NCP, and income and education level differences can influence the valuation of contributions.

3. The most relevant benefits are related to basic needs (like subsistence, health, and income generation) and the biggest problem concerns the environmental conditions of the communities.

4. The communities have a positive opinion of nearby PAs despite being underused.

We hope that this study will pave the road for decision-making in socioeconomically and environmentally vulnerable rural communities on Eastern Amazon.

\section{Materials and Methods}

The theoretical framework shown in Figure 1 was based on previous studies addressing the importance of NCP $[28,42,43]$, and summarizes the underlying concepts and targets of the present study. The framework shows that NCP depends on elements of the ecological system, which, in turn, can contribute to human well-being (according to the use, perception, and information acquired). 
The value that people attribute to nature contributions is based on the perception of benefits and problems, and their expressed preferences, which may guide decision-making towards improving the overall conditions of the system.

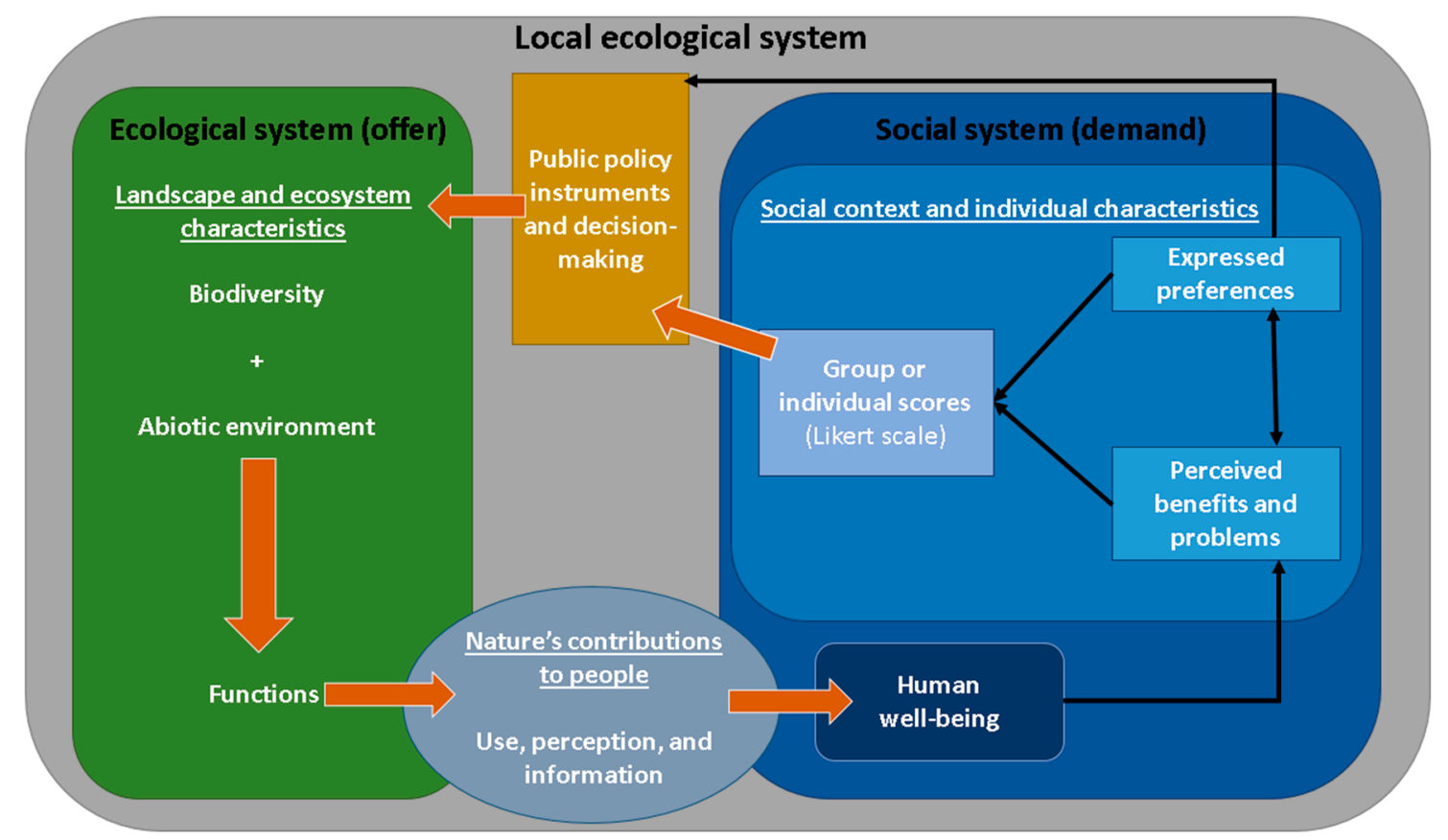

Figure 1. Theoretical framework of the present study.

\subsection{Study Site}

Parauapebas is a municipality located in the southeast of Pará state, in the Eastern Amazon, within the area known as the Deforestation Arc. Its area is $6886.2 \mathrm{~km}^{2}$, and its estimated population was approximately 203,000 inhabitants in 2018 [40]. From 1991 to 2010, the percentage of the rural population has decreased from approximately 50\% to only 10\% [40]. According to the 2010 census, the municipality had 42,719 households, 3835 in rural areas $(8.4 \%)$. Projecting a proportional loss of rural residents, we estimate that the rural population is nearly 18,000 inhabitants (that is, approximately $8.5 \%$ of the total population). In 2017, the Brazilian Institute of Geography and Statistics (IBGE) estimated that 4732 people worked on farms.

The main economic activities of the municipality are agriculture and mining [44], with the latter being conducted in a sustainable-use protected area, the Carajás National Forest. Although approximately $80 \%$ of the municipality's area is still in protected areas and indigenous land, since 1980s, Parauapebas has lost nearly $20 \%$ of its native forests [45], which were primarily converted into pastures [46]. The study communities are relatively close to the Pas, despite being surrounded by very degraded areas (animal husbandry) (Figure 2).

The study site encompasses five rural communities located in Parauapebas (Figure 2): Igarapé Gelado Environmental Protection Area (Área de Proteção Ambiental-APA), Santo Antônio, Nova Esperança, Onalício Barros, and Palmares II. These communities were formed a few decades ago by rural migrant workers encouraged by national programs for the occupation of the Amazon. Four of them are less than three kilometers away from the Carajás National Forest, and only Palmares II is located further. The Igarapé Gelado APA is inserted in a protected area that allows sustainable exploration and presents better environmental conditions, showing a larger proportion of forest cover; however, the others are located in more degraded environments (Supplementary Material Figure S1). 


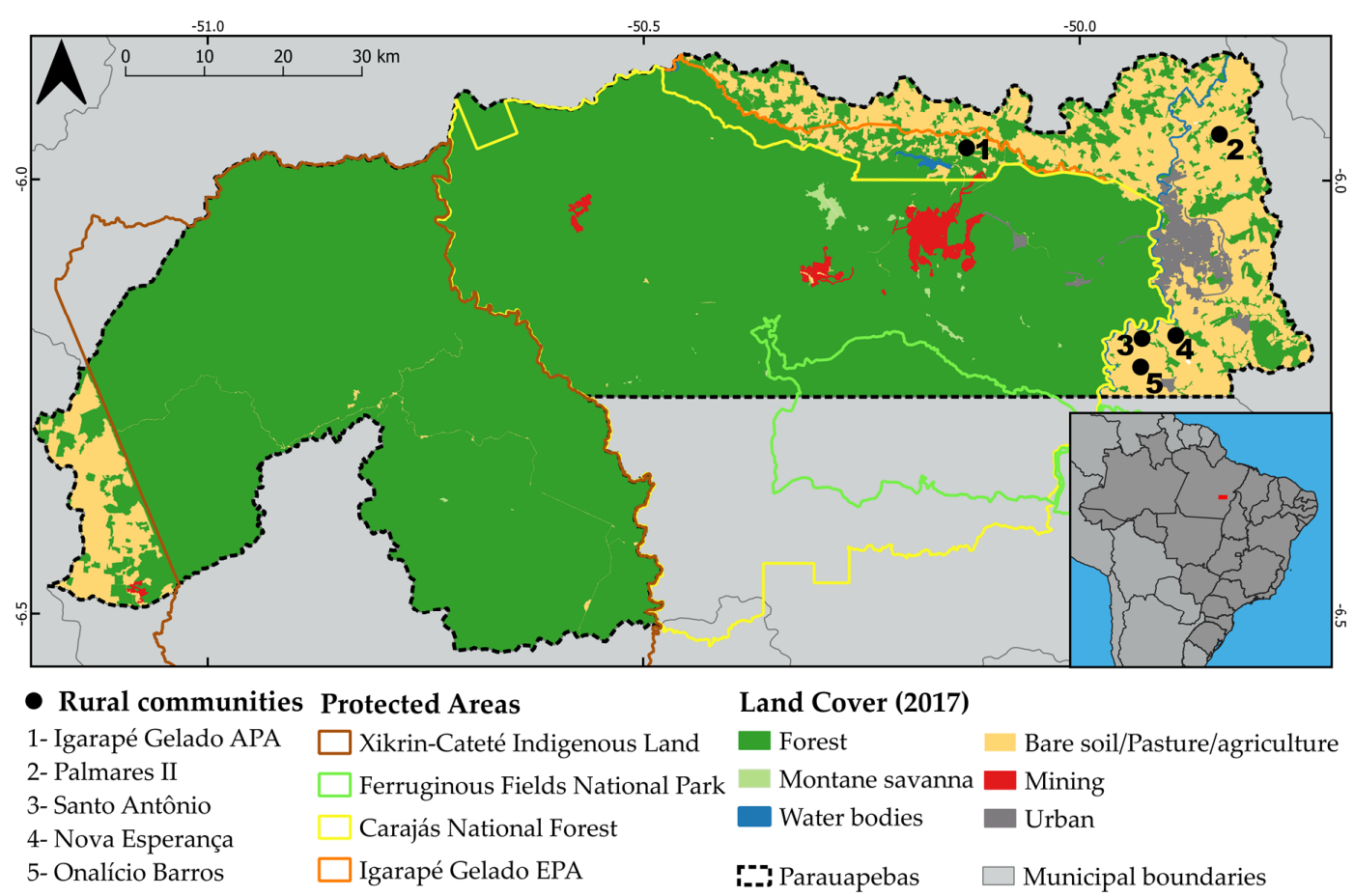

Figure 2. Location of the rural communities studied on Parauapebas, including the protected areas (PA) and land-cover (2017).

We chose the five communities above mentioned because they are located on the edge of one of the few fragments of pristine Amazon forest, within the Arc of Deforestation (Fearnside 2006), in the Eastern Amazon. To date, no other study has been conducted in a location with such characteristics, where the presence of the Amazon tropical forest contrasts sharply with the intense deforestation in the vicinity, due to agricultural activities (Souza-Filho et al. 2016). We believe that such a contrast provides a unique situation for analyzing people's perception of NCP.

\subsection{Sample Definition and Data Collection}

To calculate the sample, we estimated the number of households of each community, with a $95 \%$ confidence level and a margin of error of approximately $10 \%$ for the Palmares II community (due to the high number of households) and 8\% for the other study communities (Supplementary Material Table S1).

To prepare the questionnaire, the main NCP that could be evaluated in tropical regions and rural communities were identified, as were the most important socioeconomic and demographic characteristics, to profile the communities. The NCP were divided into three categories addressing at least fifteen contributions [5,6]: [i] material NPC: crop farming, water, wood, animal husbandry, hunting, and forest products; [ii] regulating NPC: contributions provided by riparian forests, by soil fertility, fauna, regulation of air and water, and pest control; [iii] non-material NPC: natural heritage, recreation, spirituality, and ecotourism.

The administered questionnaire (Supplementary Material Table S2) was structured into four parts and covered various aspects: (1) respondent profile, surveying socioeconomic and demographic data (such as age, schooling, place of birth, occupation, residence time in Parauapebas); (2) socioeconomic characteristics, gathering family and household data (such as family income, number of residents, sewage); (3) perception of the fifteen NCP, with questions about their main benefits and problems, and their rating using a score ranging from 1 to 5 points (Likert scale), wherein 1 meant Hardly important, 2 Slightly important, 3 Important, 4 Quite important, and 5 Very important, according to importance; and (4) residents' perception of the nearby presence of PAs, who were asked to identify the PAs, to express their opinion about them, and whether they used them or not. We used the method 
proposed by Rojas et al. [36] to cluster the contributions into principal components and to relate them to the categories of socioeconomic variables.

From 19 to 24 of March 2019, we conducted field research through face-to-face interviews with our overall sample of 214 households based on the questionnaire (Supplementary Material Table S2). Our team of eight people (grouped in four pairs) approached the interviewees in their homes. We selected households randomly, seeking to cover the entire area of each community. In each household, we chose the available members with 18 years of age or older and with knowledge to answer all questions of the questionnaire. On average, each interview lasted about $20 \mathrm{~min}$. We respected the anonymity of the respondents, following the ethical research standards of Instituto Tecnológico Vale [47], and conducted the interviews after receiving their verbal consent.

\subsection{Data Collection and Analyse}

\subsubsection{Socioeconomic Profile}

The socioeconomic profile of each community was determined based on occupation, gender, age, schooling, residence time, household income, and whether the individual was a food producer. We calculated the frequencies and the percentage of each class of these variables.

We organized occupation into nine different groups, following the categories defined by the International Labour Organization [48]. We divided age into four groups, following Rojas et al. [36], which separates adults into young adults (18-35 years), intermediate adults (36-49 years), mature adults (50-64 years), and seniors (>65 years). Schooling was grouped by years of study according to the stages of education in Brazil, ranging from people who never attended school (zero years) to those who completed primary school I (4) and II (9), secondary school (12), and technical, graduate or postgraduate degrees (more than 12). The mean was compared with indicators of the National Household Sample Survey (PNAD) of 2015 [49]. Since the 1980s, the mining industry in Carajás has attracted many migrants to Parauapebas in connection with new projects introduced in the region. We divided the interviewees' residence time relative to fieldwork date into three periods: 32 to 45 years (before the establishment of the municipality and before mining); 16 to 31 (iron mining); and zero to 15 years (start of copper mining).

To calculate any similarities between communities, we used Student's $t$-test.

\subsubsection{NCP Score}

From the importance scores assigned on the Likert scale, we calculated the means to determine which contributions were considered individually more relevant by the interviewees. We used principal component analysis (PCA) to cluster and reduce the number of components (separately for each NCP) and to evaluate the relationship with socio-environmental variables by comparing means (using the Mann-Whitney U and Kruskal-Wallis tests for variables with two or more categories, respectively). We assessed the suitability of the scores on the Likert scale adopted using the Kaiser-Meyer-Olkin (KMO) test, in line with the literature; we considered levels higher than 0.5 acceptable [30]. In addition to differentiating communities, we categorized the data according to the occupation, gender, age, schooling, and residence time of the respondents, and whether they benefitted from a social program. We used R's packages [50] and Excel software to do the statistical tests.

\subsubsection{Benefits and Problems}

The respondents (with mention of one or more items) spontaneously cited the benefits of each NCP. We organized these benefits according to three NCP classes. To plot the number of mentions of benefits, according to the different groups of contributions, we followed two steps: first, we grouped them according to their meaning; then, we organized them as a function of their number of mentions. For example, among the material benefits, some people pointed to food, whereas others mentioned subsistence; some cited trade, others income. Even though they referred to these benefits differently, 
their meaning was the same. Thus, we computed them together. We classified the less commonly cited benefits as other benefits. The interviewees also freely and spontaneously cited one or more problems.

Other quoted benefits related to NCP materials are medicinal use, animal consumption, household activities, firewood, charcoal, health, leather, fertilizer, handicrafts, cosmetics, ornamental plants, seed collection, furniture, and utensils production, and irrigation. The benefits related to regulatory $\mathrm{NCP}$, classified as environmental protection, are water protection, shading, protection against erosion and silting, fauna and flora, climate control, flood control, forest maintenance, and aesthetic beauty. Among others, respondents quoted: well-being, leisure, reduced work, reduced use of chemical fertilizers, improved pasture, guaranteed financial return, pest control, environmental balance, water quality, protection, and increased product value. For the benefits related to non-material NCP classified as well-being and quality of life, there are tranquility, leisure, relaxation, calm, peace, concentration, good thoughts, relief, joy, and appreciation. Classified as the quality of the environment, they quoted clean air, shading, environmental balance, pleasant climate, protection of fauna, bird and other animal watching, sport fishing, and conservation. As for spirituality, they quoted the sense of belonging, existence, religiosity, inspiration, contemplation, meditation, and being close to God. Among others, they quoted subsistence, income, the guarantee of future generations, and knowledge.

Among material NCP, we separated the problems into eight groups: environmental degradation (loss of habitat, water, and air pollution and burning); affecting the fauna (animals' mistreatment, risk and extinction, and hunting); restrictions (lack of land, AP limits, burning prohibitions, licensing of environmental agencies and penalties for breaking the law); costs (medicines, food, transportation, and agricultural inputs); product distribution (infrastructure and transport); natural problems (floods, infertile soil, pests, droughts, and microclimate); risks (wild animals, from collecting products in the forest); lack of support (public, financial, technological and inputs). In the regulatory NCP, we also divided the problems into eight groups: environmental degradation (deforestation, pollution, erosion, burning and environmental imbalance); diseases; decreased productivity: pesticides use; affecting water resource (silting, erosion, floodplain occupation, and water shortages); natural problems (flooding, infertile soil, drought, and pests); others (high temperature, costs, lack of technical support, mining and heavy work); increased fertilizer use. In non-material NCP, six groups were mentioned: environmental degradation (pollution, burning, and deforestation); negative impacts (social impacts due to the presence of unknown people, such as pollution and violence); accessibility (costs, free time, distance); risks (diseases and wild animals); lack of support (public infrastructure); others (scarcity of resources, awareness, weak tourism, restricted areas).

\subsubsection{Protected Areas}

We calculated the percentages of respondents who were or not aware of the existence of PAs and those who stated that Parauapebas had no PA. Then we calculated the number of respondents who knew each of the protected areas, and we listed the occurrence of positive, negative, and indifferent opinions, as well as observations about such views. Last, we grouped the main mentioned uses of these areas.

We organized the observations about opinions into the following groups: (1) environmental conservation (with mentions of nature conservations and protection); (2) fauna and flora protection (references to animal, plant and tree protection); (3) other problems (checkpoints, lack of access, mining impact, and ban on agriculture); and (4) climate change mitigation (greenhouse gas reduction, microclimate improvement).

In turn, we organized the uses as follows: (1) visiting and leisure (walk in the zoo-botanical park, visiting relatives or friends, camping, educational tours); (2) no use; (3) place of residence (people who live in the PA); (4) study/work (attend school or work); (5) extractivism/sustainable use (sporadically extract some forest product, such as fruit or wood); and (6) other uses (hospital, market, and meetings; there is a small urban area inside the Carajás National Forest). 


\section{Results}

\subsection{Socioeconomic Characteristics of the Communities}

The age of the respondents of the five communities ranged from 18 to 79 years, with a mean of $43.5 \pm 15.8$ years. In total, 98 men $(46.2 \%)$ and 116 women (53.8\%) were interviewed (Table 1$)$. The average schooling was of $7.8 \pm 4.5$ years, with variation in the sample, ranging from zero and twenty-two. The monthly income of most (52\%) households was lower than one minimum wage, or USD 250 (http://www.previdencia.gov.br/). Nearly 86\% of respondents were born in other municipalities, and the mean residence time was approximately 19 years, ranging from 0 to 45 years.

Table 1. Socioeconomic profile of rural communities and household conditions.

\begin{tabular}{|c|c|c|c|c|c|c|c|c|c|c|c|c|c|}
\hline \multicolumn{2}{|c|}{ Variables } & \multicolumn{2}{|c|}{$\begin{array}{l}\text { I.Gelado } \\
\text { APA }\end{array}$} & \multicolumn{2}{|c|}{ Nova Esperança } & \multicolumn{2}{|c|}{ Onalicio Barros } & \multicolumn{2}{|c|}{ Palmares II } & \multicolumn{2}{|c|}{ Santo Antônio } & \multicolumn{2}{|c|}{ Overall } \\
\hline \multicolumn{2}{|c|}{ Definition } & \multicolumn{2}{|c|}{$\mathrm{N}=39$} & \multicolumn{2}{|c|}{$\mathrm{N}=27$} & \multicolumn{2}{|c|}{$\mathrm{N}=\mathbf{2 7}$} & \multicolumn{2}{|c|}{$\mathrm{N}=104$} & \multicolumn{2}{|c|}{$\mathrm{N}=17$} & \multicolumn{2}{|c|}{$\mathrm{N}=214$} \\
\hline & & $n$ & $\%$ & $n$ & $\%$ & $n$ & $\%$ & $n$ & $\%$ & $n$ & $\%$ & $n$ & $\%$ \\
\hline \multirow{7}{*}{ Occupation } & Retiree & - & - & - & - & - & - & 6 & 5.9 & - & - & 6 & 2.5 \\
\hline & Unemployed & 1 & 2.6 & 7 & 26.9 & 4 & 14.8 & 14 & 13.7 & - & - & 26 & 12.3 \\
\hline & Homemaker & 7 & 18 & 5 & 19.2 & 6 & 22.2 & 27 & 26.5 & 2 & 11.8 & 47 & 22.3 \\
\hline & Agriculture & 17 & 43.6 & 9 & 34.6 & 7 & 25.9 & 19 & 18.6 & 12 & 70.6 & 64 & 30.3 \\
\hline & $\begin{array}{l}\text { Goods and } \\
\text { services }\end{array}$ & 1 & 2.6 & - & - & 1 & 3.7 & 6 & 5.9 & - & - & 8 & 3.8 \\
\hline & Trade & 11 & 28.2 & 4 & 15.4 & 4 & 14.8 & 16 & 15.7 & 2 & 11.8 & 37 & 17.5 \\
\hline & Others & - & - & - & - & 1 & 3.7 & 6 & 5.9 & 1 & 5.9 & 8 & 3.8 \\
\hline Gender & Male & 21 & 56.8 & 12 & 44.4 & 10 & 37.0 & 47 & 45.2 & 8 & 45.2 & 98 & 46.2 \\
\hline Age & $66-79$ & 2 & 5.3 & 5 & 20 & 3 & 11.1 & 10 & 9.6 & 1 & 6.3 & 21 & 10 \\
\hline & 0 & 3 & 7.7 & 4 & 16 & 2 & 7.4 & 15 & 14.9 & - & - & 24 & 11.5 \\
\hline & $1-4$ & 7 & 18 & 5 & 20 & 3 & 11.1 & 14 & 13.9 & 2 & 11.8 & 31 & 14.8 \\
\hline Schooling & $5-9$ & 12 & 30.8 & 8 & 32 & 11 & 40.7 & 27 & 26.7 & 9 & 52.9 & 67 & 32.1 \\
\hline & $10-12$ & 14 & 35.9 & 6 & 24 & 10 & 37.0 & 40 & 39.6 & 5 & 29.4 & 75 & 35.9 \\
\hline & $>12$ & 3 & 7.7 & 2 & 8 & 1 & 3.7 & 5 & 5.0 & 1 & 5.9 & 12 & 5.7 \\
\hline & $0-15$ & 10 & 27.0 & 14 & 56 & 15 & 53.9 & 39 & 38.2 & 9 & 38.2 & 86 & 41.8 \\
\hline Residence & $16-31$ & 22 & 59.5 & 9 & 36 & 9 & 34.6 & 48 & 47.1 & 5 & 47.1 & 93 & 45.2 \\
\hline & $32-45$ & 5 & 13.5 & 2 & 8 & 3 & 11.5 & 15 & 14.7 & 2 & 14.7 & 27 & 13.1 \\
\hline & $<0.5 \mathrm{mw}$ & 3 & 7.7 & 4 & 14.8 & 5 & 18.5 & 21 & 20.2 & 4 & 23.5 & 37 & 17.3 \\
\hline & $0.5-1 \mathrm{mw}$ & 16 & 41.0 & 10 & 37 & 9 & 33.3 & 34 & 32.7 & 5 & 29.4 & 74 & 34.6 \\
\hline & Owner-occupied & 30 & 76.9 & 24 & 88.9 & 22 & 81.5 & 81 & 77.9 & 15 & 88.2 & 172 & 80.4 \\
\hline & Private rented & 3 & 7.7 & 2 & 7.4 & - & - & 6 & 5.8 & 1 & 5.9 & 12 & 5.6 \\
\hline Property & Council house & 5 & 12.8 & 1 & 3.7 & 5 & 18.5 & 16 & 15.4 & 1 & 5.9 & 28 & 13.1 \\
\hline & Other & 1 & 2.6 & - & - & - & - & 1 & 1 & - & 0 & 2 & 0.9 \\
\hline & Sewerage & - & - & 1 & 3.7 & 1 & 3.7 & 3 & 2.9 & 1 & 5.9 & 6 & 2.8 \\
\hline & Septic tank & 35 & 89.7 & 22 & 81.4 & 23 & 85.2 & 90 & 86.5 & 12 & 70.6 & 182 & 85.1 \\
\hline Sewage & Open sewer & 4 & 10.3 & 4 & 14.8 & 3 & 11.1 & 8 & 77 & 4 & 23.5 & 23 & 10.8 \\
\hline & River/creek & - & - & - & - & - & - & 1 & 1 & - & - & 1 & 0.5 \\
\hline & Not identified & - & - & - & - & - & - & 2 & 1.9 & - & - & 2 & 0.9 \\
\hline & $\begin{array}{l}\text { Water supply } \\
\text { network }\end{array}$ & 15 & 38.5 & 12 & 44.4 & 10 & 37 & 51 & 49 & 7 & 41.2 & 95 & 44.4 \\
\hline Water & Well/spring & 23 & 59 & 15 & 55.6 & 16 & 59.3 & 48 & 46.2 & 10 & 58.8 & 112 & 52.3 \\
\hline & River & 1 & 2.6 & - & - & 1 & 3.7 & 4 & 3.9 & - & - & 6 & 2.8 \\
\hline & Tank & - & - & - & - & - & - & 1 & 1 & - & - & 1 & 0.5 \\
\hline & With metre & 23 & 59 & 22 & 81.5 & 18 & 66.7 & 68 & 65.4 & 9 & 52.9 & 140 & 65.4 \\
\hline Electricity & Without metre & 16 & 41 & 5 & 18.5 & 6 & 33.3 & 36 & 34.6 & 8 & 47.1 & 74 & 34.6 \\
\hline
\end{tabular}

( $n$ and $\%$ are the absolute and relative numbers of the interviewees, respectively; $\mathrm{mw}=$ minimum wage). 
Of the 214 respondents, $64(30.3 \%)$ had agriculture-related occupations-farming or animal husbandry (Table 1) - and 73 (nearly 35\%) were outside the formal labor market (self-declared as homemakers or unemployed). We also noted that 123 respondents $(57.5 \%)$ grew crops for their subsistence (Table 1).

Approximately 52 and 44 percent of families used a well and network for their water supply, respectively, and about $3 \%$ took it from a river or tank. Eighty percent of respondents lived in their own houses in their land, $13 \%$ in council houses, $6 \%$ by rent, and $1 \%$ on another type of property (Table 1 ). Regarding sewage disposal, 85 and nearly 11 percent of properties used septic tanks and an open sewer, respectively. About $3 \%$ had a connection with the water supply network, and approximately $1 \%$ discharged sewage into rivers or creeks, or in unidentified destinations. All households accessed public energy sources, with (65\%) and without (35\%) an electricity meter (Table 1).

When comparing the socioeconomic profiles of the five communities, we found no significant differences between them, that is, the community profile was quite homogeneous. For example, the results from the Student's $t$-test of differences in mean age $(p=0.17)$, schooling $(p=0.052)$, income $(p=0.55)$, and residence time $(p=0.08)$ showed that the communities had similar values (5\% significance).

The performance of the study communities was related to slightly worse schooling (than that of the reference region) and to a high percentage of low household income, so the first hypothesis that the households show socioeconomic vulnerability was confirmed.

\subsection{Importance of NCP}

The importance scores assigned to the NCP groups showed that all NCP were considered important, quite important, or very important (scores ranging from 3 to 5 points) by over $75 \%$ of respondents (Figure 3). Almost all services had the highest score on the scale (very important), with approximately $2 / 3$ respondents assigning this score to material contributions and approximately $3 / 4$ and $4 / 5$ doing so to non-material and regulating contributions, respectively (Figure 3 ).

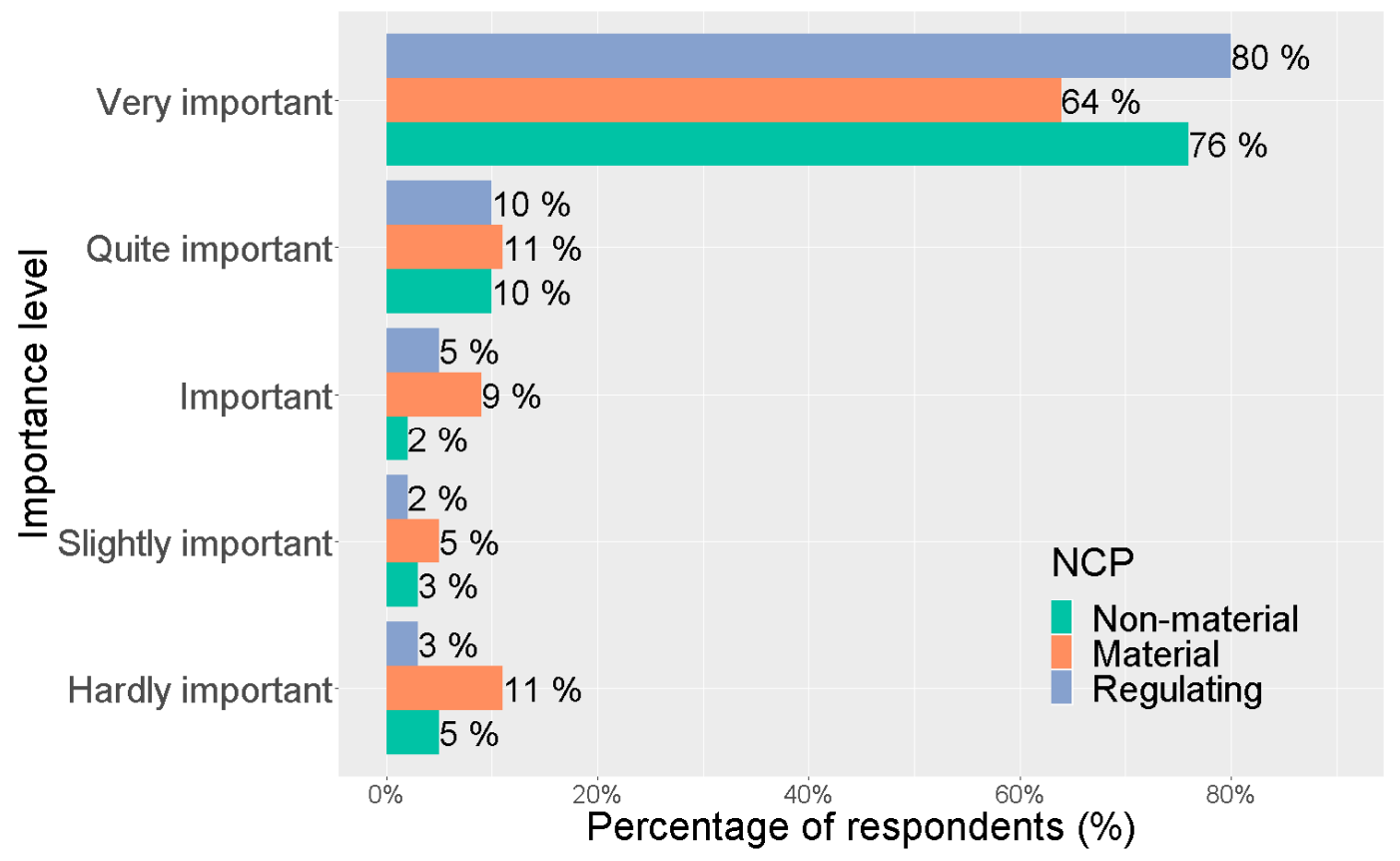

Figure 3. Values attributed to the different categories of nature's contributions to people(NCP) (Likert scale).

In general, contributions related to water and air regulation, to water, and the value of nature had the highest importance scores, followed by the scores of contributions from riparian forests, soil fertility, 
and crop farming. The interviewees assigned the lowest scores to hunting, ecotourism, and forest products, respectively, followed by wood use and animal contributions (Supplementary Material Table S3).

We structured the category material NCP into three components, which combined explain nearly $64 \%$ of all variance (Table 2). The first term, labelled as animal husbandry, timber, and non-timber resources, explained $26 \%$ of the variance and included wood, animal husbandry, and the use of forest products. The second component, related to water and hunting, explained $20 \%$ of the variance; the third one, related to crop farming, explained $18 \%$ of it.

Table 2. Principal component analysis of the three NCP categories.

\begin{tabular}{|c|c|c|c|c|}
\hline \multirow[t]{2}{*}{ KMO } & \multirow{2}{*}{$\frac{\text { NCP }}{\text { Material }}$} & \multicolumn{3}{|c|}{ Component } \\
\hline & & 1 & 2 & 3 \\
\hline 0.65 & Wood & 0.559 & & \\
\hline 0.66 & Animal husbandry & 0.532 & & \\
\hline 0.63 & Forest products & 0.398 & & \\
\hline 0.60 & Hunting & & 0.497 & \\
\hline 0.38 & Water & & 0.774 & \\
\hline \multirow[t]{3}{*}{0.53} & Agriculture & & & 0.651 \\
\hline & Cumulative Variance (\%) & 26.19 & 45.77 & 63.88 \\
\hline & Regulating & 1 & 2 & 3 \\
\hline 0.66 & Riparian forest & 0.579 & & \\
\hline 0.65 & Soil fertility & 0.480 & & \\
\hline 0.56 & Air/water regulation & 0.472 & & \\
\hline 0.65 & Pest control & & 0.773 & \\
\hline \multirow[t]{3}{*}{0.56} & Animals-plants & & & 0.896 \\
\hline & Cumulative Variance (\%) & 26.97 & 47.85 & 66.80 \\
\hline & Non-material & 1 & 2 & 3 \\
\hline 0.67 & Recreation & 0.546 & & \\
\hline 0.71 & Natural heritage & 0.516 & & \\
\hline 0.61 & Spirituality & 0.514 & & \\
\hline \multirow[t]{2}{*}{0.78} & Ecotourism & & 0.832 & \\
\hline & Cumulative Variance (\%) & 42.44 & 64.66 & \\
\hline
\end{tabular}

The category of regulating contributions consisted of three components, which, together, explained $67 \%$ of the variance (Table 2). The first component, related to the factors that protect and ensure the maintenance of socio-ecological systems (soil and water quality, production guarantee, improved environmental quality) explained $27 \%$ of the variance. It grouped the contributions of riparian forests, soil fertility, and water and air regulation. The second component, related to pest control, explained $21 \%$ of the variance, whereas the third one, concerning animal contributions to plants, explained $19 \%$ of it.

We grouped non-material contributions into two components, which explained $64 \%$ of the variance (Table 2). The first component, labelled as immaterial value, and recreation, consisted of contributions related to the value of forests and rivers, recreation, and spirituality, explaining $42 \%$ of the variance. The second one, ecotourism, explained $22 \%$ of it.

The analysis of the relationship between NCP scores and socioeconomic variables showed significant differences between age groups, genders, and beneficiary statuses of social programs concerning water and hunting (Supplementary Material Table S4). The score that had significant differences in the importance given to components, according to the different socioeconomic groups categorized (below 0.05), was emphasized. The first component of material NCP (animal husbandry, timber, and non-timber products) showed significant differences between communities ( $p=0.002)$; the second one (hunting) showed differences between ages $(p=0.038)$, genders $(p=0.002)$, and welfare 
beneficiary statuses $(p=0.036$ ); the third component of material NCP (agricultural resources) showed differences between genders $(p=0.022)$; and the second component of regulating NCP (pest control) also showed significant differences between genders $(p=0.005)$.

In the above categories, the intermediate age group, men, and beneficiaries of social programs gave high scores to water and hunting. Regarding animal husbandry, timber, and non-timber resources (first component of material NCP), the communities Palmares II and Onalício Barros assigned low scores. Women indicated lower scores to water, hunting, agricultural products, and pest control.

Thus, we partly corroborated our second hypothesis because communities placed a high value on all NCP categories, but regulating NCP and non-material NCP were considered the most important. Differences in income and education level had no influence on the valuation of contributions.

\subsection{Main Benefits and Problems Related to NCP}

\subsubsection{Benefits}

The main material contributions cited included food/livelihood (the most cited contribution in all communities), either for crop farming, animal husbandry, access to water, forest products, or hunting; trade/income, primarily regarding agricultural products and animal husbandry; and wood used for construction (Figure 4). In all communities, the most cited benefit was food and livelihood (Supplementary Material Figure S2).

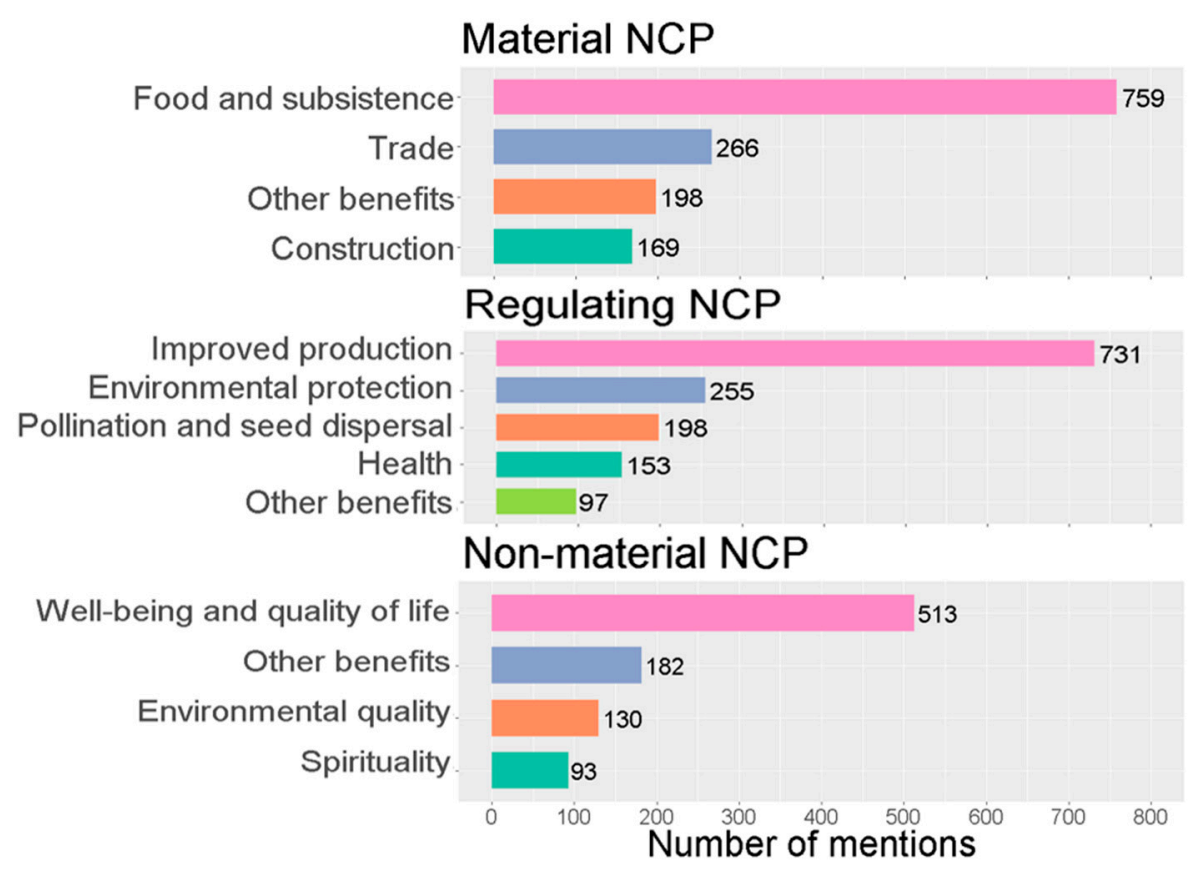

Figure 4. Benefits mention in the three categories of the NCP.

The increase in food crop yield and quality were the main benefits cited among regulating contributions, followed by environmental protection, health benefits, and seed dispersal and pollination functions performed by animals (Figure 4). In all communities, increases in the quantity and quality of products were, together, the most commonly mentioned benefits (Supplementary Material Figure S2).

The main benefits of the non-material contributions included well-being and quality of life, followed by others, environmental quality, and spirituality (Figure 4). All communities mentioned benefits related to well-being and quality of life more often than any other category (Supplementary Material Figure S2).

The individual contributions showed that water had the highest scores among material NCP, and domestic use was its biggest benefit indicated by the respondents. The benefits of NCP related to crop 
farming and animal husbandry were food and income generation through trade. Although wood use and consumption of forest products were considered significant, their scores were lower than those of the mentioned NCP. In the case of wood, the interviewees pointed out that their uses were related to construction (houses, fences, and furniture) and firewood; as for forest products, they quoted food, trade, and medicinal. Few respondents assigned a high score to hunting, indicating food as the main benefit.

In general, regulating NCP had the highest importance scores. Individually, water and air regulation had the highest importance score; its main mentioned benefit was health improvement. The most commonly mentioned contribution of riparian forests was river protection and environmental conservation support (habitat guarantee). The main benefits of pest control were related to increased crop production and quality. The contributions from animals had the lowest importance scores in this category, and their main cited benefit was seed dispersal and pollination.

Concerning non-material NCP, the most valued contribution was natural heritage. Its benefit, according to the respondents, was felt in the form of quality of life. Recreation was the second-most valued contribution and was primarily related to access to municipal spas and rivers for bathing and fishing. Natural heritage was the most commonly mentioned benefit when asking about the spiritual value of nature, followed by a sense of peace, tranquility, calmness, and well-being. Lastly, the main benefit of ecotourism mentioned by the respondents was access to knowledge brought by people from other places and income generation in communities, though it scored lower, on average, than other non-material NCP.

Regarding benefits, we corroborated our third hypothesis, since the benefit considered most important was food and livelihood, associated with the category material NCP.

\subsubsection{Problems}

Regarding material NCP, as explained above, the main groups of problems mentioned by the respondents were environmental degradation, followed by the effects on the fauna, restrictions, and costs. With fewer than 100 mentions, problems related to product distribution, nature, risks, and lack of support were also brought up (Figure 5).

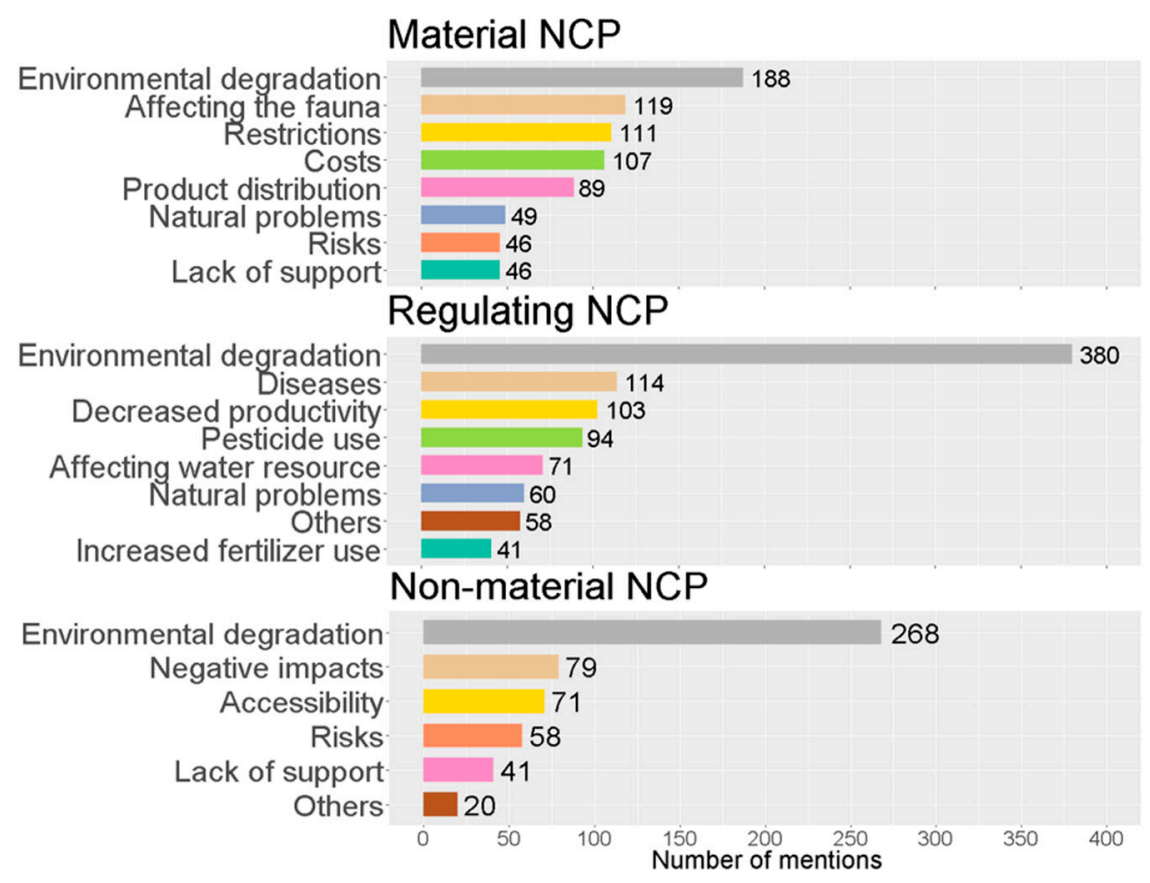

Figure 5. Problems mention in the three categories of the NCP. 
Except for Igarapé Gelado APA, in all other communities, most respondents mentioned environmental degradation problems. Problems related to restrictions (regarding material NCP) had the highest proportion of mentions in Igarapé Gelado APA (Supplementary Material Figure S3). The number of mentions of problems related to product distribution in Palmares II, proportionally higher than that in other communities, also stood out (also regarding material NCP).

Most respondents stated that the water was of good quality, but the lack of distribution in the water supply network was among the main problems reported, often due to the low pressure that prevented water from reaching homes. Regarding crop farming, the most cited problems were lack of land, poor product distribution, and lack of technical support/funding. A much-cited problem regarding animal husbandry was the cost of inputs (feeds and medicines needed to fight disease). Regarding wood, the interviewees said it was related to shortage and deforestation. The main problems with forest products were collection and depletion risks (due to lack of management) and lack of access to PAs. Concerning hunting, the interviewees reported defaunation, hunting as an environmental crime, and its degradation.

In relation to regulating NCP, again the most cited problems were linked to environmental degradation, followed by health hazards (diseases), reduced product quantity and quality, and pesticide use. With even fewer citations, water resource problems, natural problems, the category others, and increased chemical fertilizer use were also brought up (Figure 5). The community Nova Esperança stood out for its higher proportion of respondents who mentioned the problem related to increased chemical fertilizer use. The other mentions were quite similar (Supplementary Material Figure S3).

Regarding air and water regulation, the main concern referred to pollution and its inherent health hazards. Problems related to riparian forests referred to the degradation of those areas. Increased chemical fertilizer use and soil depletion were the most commonly mentioned problems, referring to the contribution of soil fertility. The main problems of pest control, according to the respondents, in addition to pesticide use, were the resulting soil, water, and air contamination. Many declared that they believed that animals and insects only damaged crops, ultimately decreasing the yield. However, others indicated environmental degradation and its imbalance that was reducing the number of animals as the main problems.

Concerning non-material NCP, problems related to environmental degradation were the most cited in general, followed by negative impacts and accessibility problems. Among the least cited were risks, lack of support, and others. The lower proportion of mentions of environmental degradation in the community Igarapé Gelado APA stood out in the category material NCP (Supplementary Material Figure S3).

The interviewees said the main perceived problems with the natural heritage were related to forest degradation and river pollution. Most respondents reported no problems related to recreation, but they commonly cited lack of access and some risk in natural areas (such as wild animals). The interviewees did not mention any problem related to spirituality; nor many problems with ecotourism, although they most cited the risk of pollution and possible negative impacts.

Concerning problems, we confirmed our third hypothesis, because the problem considered most important was environmental degradation, associated with the category regulating NCP.

\subsection{Perception and Importance of Protected Areas}

Of the 214 respondents, 177 (83\%) stated that they were aware that PAs existed in the municipality, 19 that no such PAs existed (9\%), and 17 did not know the answer (8\%).

Among the respondents who affirmed that PAs existed in the municipality, $73 \%$ declared that they were aware of the existence of the Carajás National Forest, and few stated that they knew other areas (Figure 6). Most of the respondents who declared that they used or did not use a PA stated that, as of the study date, they had gone to the zoo-botanical park or to the Carajás Centre (both in the small urban area) to visit friends or relatives at least once. A significant number of respondents also stated that they did not use these areas for any purpose (Figure 6). 


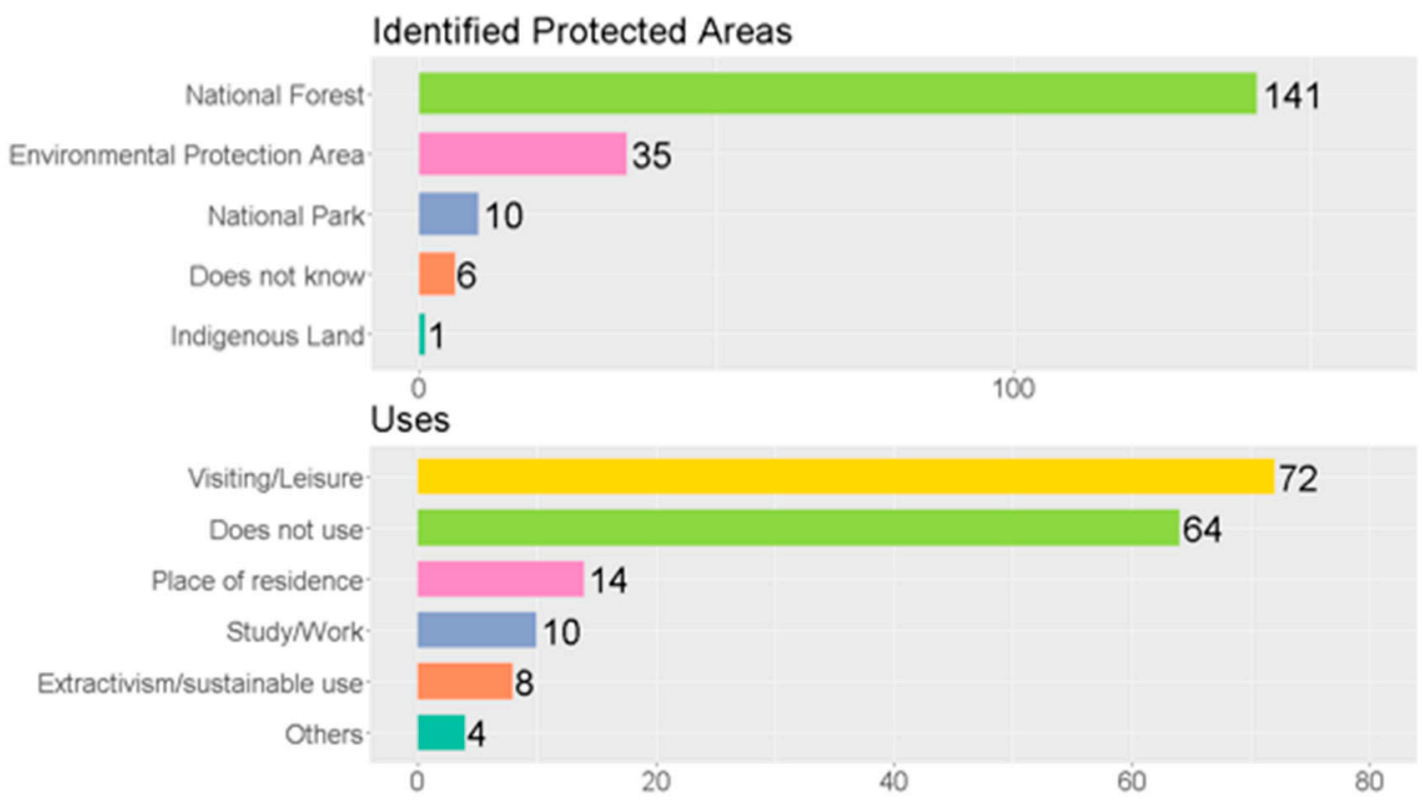

Opinions

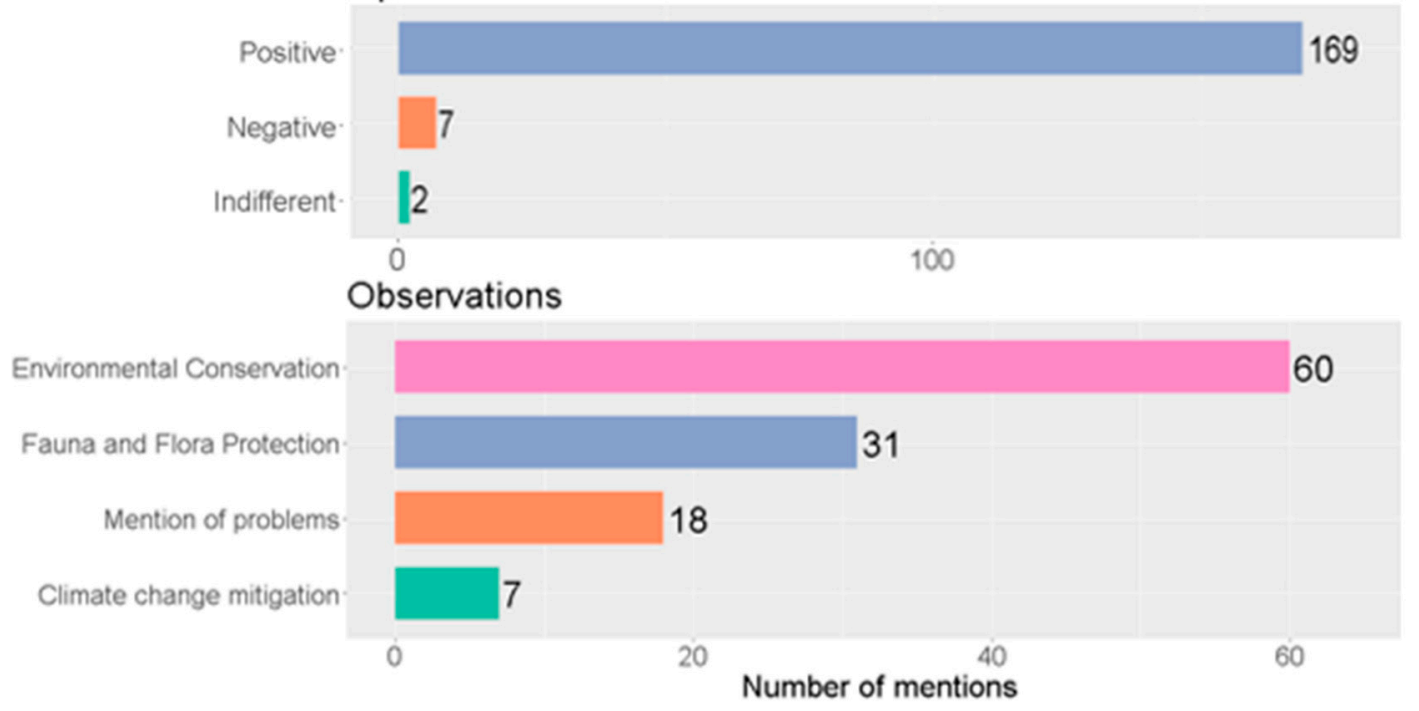

Figure 6. Frequency of identified PAs, uses, opinions, and observations about them.

Among the interviewees who said knew the existence of the PA, roughly $95 \%$ and $4 \%$ had a positive and negative opinion about it, respectively, and 1\% reported indifference (Figure 6). The main observations cited by the respondents regarding opinions are nature conservation aspects, followed by fauna and flora protection (citing animals or plants directly), and mentions of climate change problems and mitigation (Figure 6).

Thus, regarding the importance of PAs, we confirmed our fourth hypothesis, because the communities had a positive opinion about the protected areas, even though they have stated their little use of them.

\section{Discussion}

We believe that the communities studied here are representative of rural communities, especially in the Eastern Amazon. Residents, in general, are not locals, explore the land manually, and have low income and low level of schooling. However, they live relatively close to well-preserved environments covered by the rich Amazon tropical forest. Clearly, there is a contrast between the abundance of contributions provided by nature and poverty, a situation that has already been discussed [51]. 
The major results obtained here are important to understand how these communities perceive nature, the types of interactions they establish with it, and, due to these interactions, the benefits and problems reported by them. Since they come from communities whose characteristics are common in the region, the main results obtained here are potentially broad in scope, and are the first ones to analyze people's perceptions of the rich nature occurring in their surroundings in the region.

Most respondents live in houses with small backyards and work on other people's land, with low production. During the interviews, we notice several characteristics of the communities, such as a lack of infrastructure and of support in all communities. The perceptions of NCP by the interviewees are probably grounded on these socio-economic conditions, and on their close relationship with nature.

The communities studied were socially and economically similar, and most respondents considered the three categories of NCP as being critical, corroborating results from another study on rural areas [34-36]. The comparison between socioeconomic profile clusters demonstrated few differences in the perception of the value of NCP. The contributions directly and indirectly related to livelihood and quality of life had the highest scores. The most commonly mentioned problems were related to environmental degradation in all NCP categories. Nearly all respondents had a positive opinion of municipal PAs, especially regarding conservation, despite stating that they made little use of them.

The five communities were rather homogeneous, mostly consisting of migrants from various Brazilian locations with a relatively lower level of schooling than residents of the reference regions-residents of Pará state and residents of Brazil as a whole [49]. The high number of persons outside the formal labor market results in a low family income; therefore, subsistence farming becomes an important activity for families. In addition, problems such as the lack of public infrastructure (sewerage, for example) and obsolete farming techniques (manual labor) undermine the quality of life of rural residents. The low level of education is correlated with differences in the scores assigned to different contributions. For example, NCP related to environmental conservation scored high, whereas NCP that could have a negative impact scored low, revealing some degree of common sense. The relatively low scores assigned to fauna and ecotourism contributions were linked to lack of knowledge.

The dependence of communities on NCP may explain the high percentage of very important (5) scores because people primarily value their survival and culture [23]. The highest scores, individually, were assigned to contributions directly or indirectly related to water (within the three NCP categories), corroborating its importance, in line with other studies conducted in different ecosystems across the world $[27,36]$. Regarding regulating NCP, the general population believes that deforestation threatens riparian forests, air, and water regulation. Some of the material NCP (related to subsistence) scored high, but their low percentage scores may be related to restrictions of other contributions (such as hunting and wood), which, as in the study conducted in rural communities in Romania [52], had (together with fishing) the lowest scores. Non-material contributions were considered quite important by $88 \%$ of respondents, assigning scores ranging from 3 to 5 to this category. Nevertheless, ecotourism did not score well, most likely due to the lack of demand for or promotion of this activity, and partly to the lack of environmental education policies in the communities, as well because some respondents did not even know the meaning of the word tourism.

The two communities that assigned the lowest scores to animal husbandry and timber and non-timber resources had the lowest percentages of agricultural workers. We found significant differences in gender in scores assigned to pest control, hunting, and agricultural products; in these latter two activities, most likely, men are more involved than women. The higher score assigned to hunting by the beneficiaries of social programs may be related to welfare subsidies given to low-income families. Therefore, direct relationships with specific activities can have an impact on perception. Perhaps this demonstrates an urbanization process in these communities, i.e., part of the population that is not directly related to land use could be willing to develop other types of activities.

The most commonly cited benefits in the categories material NCP and regulating NCP are related to livelihood, which highlights the importance of crop farming and animal husbandry for those 
communities, as well as for healthy ecosystems, which make it possible to produce more and better products. Quality of life and well-being were the most commonly cited benefits in the category non-material NCP, thus, demonstrating that having recreational opportunities and merely living near nature contributed to a positive perception of it. The most commonly cited problem in four communities was environmental degradation, most likely due to its conditions around the settlements. The exception was Igarapé Gelado APA, where the main problems were restrictions on pesticide use, logging, burns, and the need to apply for permits from the environmental protection agency to gather wood for domestic use, to use pesticides, and to enter protected areas.

Although a considerable percentage of people stated that they were unaware of PAs or denied the existence of PAs in the municipality, in general, they were highly valued by almost all people who claimed to know them, mainly for ecological rather than economic or social reasons. The few problems mentioned were related to some restrictions. Although the studied communities were very close to PAs, the use of them by most interviewees was still very limited, demonstrating there is no integration between the inhabitants and those areas; many respondents said they thought a mining company owned them. However, people can sustainably use the Carajás National Forest and the Igarapé Gelado APA, and projects incentivizing their legal use (extraction of non-timber resources, ecotourism, and environmental education, for example) could help to generate income in these communities, to heighten the sense of belonging, and to enhance conservation.

The main benefits and problems declared by the respondents make clear the importance of incentives (technical and financial), public policies and partnerships that promote the recovery of degraded areas and improve the production and distribution of food and other products, as previously pointed out in the Palmares II community [53]. There is also clear evidence supporting government actions, especially with regard to education (formal and environmental), technical training, and infrastructure. In the Brazilian Amazon, there are examples of initiatives by social organizations (associations and agricultural cooperatives), with or without the support of public or private institutions and government programs, which have brought good results related to the conservation of PA and improved production in rural communities, both in agricultural activities such as forestry [54-56].

Restoration and recovery of degraded areas with agroforestry systems, silviculture and planting of seedlings is being used in the Brazilian Amazon [57,58]. For example, the restoration of PA using palm and fruit trees (native or not), besides contributing to biodiversity protection and to local community subsistence, can also create commercial and manufacturing opportunities, adding value to products (organic cultivation certification, frozen fruit pulp). Another example would be the cultivation of woody species within the properties for personal consumption, which can reduce the demand for firewood within the PA and increase the value of forested areas within the properties. In addition, restoration also contributes to the quality of water and air, two NCP highly valued.

Peralta [59] shows that ecotourism in communities close to PA in the Brazilian Amazon, depends on partnerships (with NGOs or private institutions) for personal training (planning and management) and for the development of infrastructure, so that it results in economic and ecological gains. Environmental education policies and the training of local residents can increase the offer of opportunities for sustainable activities that could help to maintain the preserved forest. There is a great potential for income generation with the sustainable use of PAs around communities, but currently, this is almost unexplored by local inhabitants. Studies show how profitable can be the sustainable exploitation of non-timber products (Brazil nut, Jaborandi) in the Eastern Amazon [56,60], as well as the protection and recovery of forests that can attract financial incentives from international programs, such as REDD + (the reducing emissions from deforestation and forest degradation program).

A percentage of the national tax is allocated to municipalities that have PAs in Brazil, which aims to promote sustainable activities in communities close to the PA aiming to promote environmental preservation and socioeconomic development $[61,62]$. In addition to other government programs that could be replicated in municipalities in the Arc of Deforestation, integration with national, regional, and state policies could also guarantee good results in the medium and long term $[63,64]$. 
The present work brings unknown information about the perception of rural communities regarding the role of nature in their lives. Since many studies in the Amazon do not give voice to non-traditional rural communities, there is little socioeconomic information about them. The new information found here concerns the socioeconomic vulnerability of most of the inhabitants of the communities studied and the lack of public policies designed to improve the socio-environmental quality of these communities. We seek, from the information obtained, to indicate paths that could direct public policies, such as the search for financing programs, more inclusive participation of residents in the management of PAs, and the application of laws that benefit the most vulnerable people.

Further studies should compare the perceptions of rural and urban residents to highlight differences between demands and problems in the municipality. For instance, evaluating changes in ecological well-being related to the conservation of areas in China, Song et al. [65] identified a higher decline in the quality of life in rural dwellers than in urban ones, highlighting the need to establish environmental compensation policies. Racevskis and Lupi [25], who compared the perceptions of NCP of rural and urban communities (dependent and non-dependent on timber resources, respectively), indicated that rural communities prefer forest management for human use, while urban communities prefer ecological management. Alassaf et al. [27], aiming to understand the interaction between communities of arid areas in Jordan, concluded that rural dwellers are more environmentally aware of and concerned about the environment than urban dwellers. Researchers could implement another evaluation approach, supplementing the data collected with the opinions of experts from related areas. Several such studies also encompass past or future perceptions of NCP, which could be an interesting approach to learn about population expectations. We were unable to find updated secondary data from other rural communities for comparison.

\section{Conclusions}

The present study showed that the three categories of NCP obtained high rates, demonstrating the value given to them by the studied rural communities. Initiatives that seek to improve the socio-environmental conditions of poor communities are relevant, especially in degraded regions such as the rural areas of the Eastern Amazon. The perception of residents of rural communities about the importance of NCP is essential in directing decision-making, in defining policies, partnerships, and specific investments for generating income and restoring forests through sustainable activities. The involvement of communities in the management of PA can improve their living conditions and also guarantee the protection of forests. Knowing the demands and concerns of communities about the environment proves to be a valuable tool, and can be the first step towards more sustainable socio-environmental development in rural areas.

Supplementary Materials: The following are available online at http://www.mdpi.com/2071-1050/12/18/7665/s1, Figure S1: Close view of communities by satellite image; Figure S2: Benefits mentioned in each community; Figure S3: Problems mentioned in each community; Table S1: Sample calculation; Table S2: Questionnaire used in the present study; Table S3: Relevance of NCP according to the Likert-scale score; Table S4: Relationship between components and socioeconomic data.

Author Contributions: Conceptualization, R.M.d.B.; Methodology, R.M.d.B. and V.J.M.; Validation, R.M.d.B., T.C.G. and V.J.M.; Formal Analysis, R.M.d.B. and V.J.M.; Investigation, R.M.d.B. and T.C.G.; Resources, T.C.G. and V.L.I.-F; Data Curation, R.M.d.B. and V.J.M.; Writing-Original Draft Preparation, R.M.d.B.; Writing-Review \& Editing, T.C.G., V.J.M. and V.L.I.-F.; Supervision, T.C.G.; Project Administration, R.M.d.B. and T.C.G.; Funding Acquisition, T.C.G. and V.L.I.-F. All authors contributed equally to editing and revising of this review. All authors have read and agreed to the published version of the manuscript.

Funding: This research was funded by Conselho Nacional de Desenvolvimento Científico e Tecnológico- $\mathrm{CNPq}$, grant number 443381/2015-1 and 380488/2017-5.

Acknowledgments: We thank the residents of the rural communities of Parauapebas; and the team involved in the interviews. We especially thank Leonardo de Sousa Miranda and Leon Nazaré da Cruz for their help in the design of the methodology and in the rich exchange of ideas. We are also grateful to anonymous referees for their comments and suggestions in the earlier versions of the paper.

Conflicts of Interest: The authors declare no conflict of interest. 


\section{References}

1. Watson, J.E.M.; Evans, T.; Venter, O.; Williams, B.; Tulloch, A.; Stewart, C.; Thompson, I.; Ray, J.C.; Murray, K.; Salazar, A.; et al. The Exceptional Value of Intact Forest Ecosystems. Nat. Ecol. Evol. 2018, 2, 599-610. [CrossRef] [PubMed]

2. Nobre, C.A.; Sampaio, G.; Borma, L.S.; Castilla-Rubio, J.C.; Silva, J.S.; Cardoso, M. Land-Use and Climate Change Risks in the Amazon and the Need of a Novel Sustainable Development Paradigm. Proc. Natl. Acad. Sci. USA 2016, 113, 10759-10768. [CrossRef] [PubMed]

3. Fearnside, P.M. Deforestation in Brazilian Amazonia: History, Rates, and Consequences. Conserv. Boil. 2005, 19, 680-688. [CrossRef]

4. Begotti, R.A. Brazil's Indigenous Lands under Threat a Dynamic Strategy for EU Conservation Putting Invertebrate Lactation in Context. Science 2019, 363, 592.

5. Hughes, R. A conceptual framework for intelligence-based public health nutrition workforce development. Public Health Nutr. 2003, 6, 599-605. [CrossRef]

6. Díaz, S.; Pascual, U.; Stenseke, M.; Martín-López, B.; Watson, R.T.; Molnár, Z.; Hill, R.; Chan, K.M.A.; Baste, I.A.; Brauman, K.A.; et al. Assessing Nature's Contributions to People_Supl Mat. Science 2018, 359, 270-272. [CrossRef]

7. Asah, S.T.; Guerry, A.D.; Blahna, D.J.; Lawler, J.J. Perception, Acquisition and Use of Ecosystem Services: Human Behavior, and Ecosystem Management and Policy Implications. Ecosyst. Serv. 2014, 10, 180-186. [CrossRef]

8. Chan, K.M.A.; Guerry, A.D.; Balvanera, P.; Klain, S.; Satterfield, T.; Basurto, X.; Bostrom, A.; Chuenpagdee, R.; Gould, R.; Halpern, B.S.; et al. Where Are Cultural and Social in Ecosystem Services? A Framework for Constructive Engagement. BioScience 2012, 62, 744-756. [CrossRef]

9. Costanza, R.; de Groot, R.; Sutton, P.; van der Ploeg, S.; Anderson, S.J.; Kubiszewski, I.; Farber, S.; Turner, R.K. Changes in the global value of ecosystem services. Glob. Environ. Chang. 2014, 26, 152-158. [CrossRef]

10. de Groot, R.; Brander, L.; van der Ploeg, S.; Costanza, R.; Bernard, F.; Braat, L.; Christie, M.; Crossman, N.; Ghermandi, A.; Hein, L.; et al. Global Estimates of the Value of Ecosystems and Their Services in Monetary Units. Ecosyst. Serv. 2012, 1, 50-61. [CrossRef]

11. Iceland, C.; Hanson, C.; Lewis, C. Identifying Important Ecosystem Goods and Services in Puget Sound; World Resources Institute: Washington, DC, USA, 2008; p. 39.

12. Isbell, F.; Gonzalez, A.; Loreau, M.; Cowles, J.; Díaz, S.; Hector, A.; Mace, G.M.; Wardle, D.A.; O’Connor, M.I.; Duffy, J.E.; et al. Linking the Influence and Dependence of People on Biodiversity across Scales. Nature 2017, 546, 65-72. [CrossRef] [PubMed]

13. Small, N.; Munday, M.; Durance, I. The Challenge of Valuing Ecosystem Services That Have No Material Benefits. Glob. Environ. Chang. 2017, 44,57-67. [CrossRef]

14. Pascal, U.; Muradian, R. TEEB Chapter 5 The Economics of Valuing Ecosystem Services and Biodiversity. Econ. Ecosyst. Biodivers. Available online: http://www.teebweb.org (accessed on 26 March 2010).

15. Queiroz, L.S.; Rossi, S.; Calvet-Mir, L.; Ruiz-Mallén, I.; García-Betorz, S.; Salvà-Prat, J.; Meireles, A.J.A. Neglected Ecosystem Services: Highlighting the Socio-Cultural Perception of Mangroves in Decision-Making Processes. Ecosyst. Serv. 2017, 26, 137-145. [CrossRef]

16. Breeze, T.D.; Gallai, N.; Garibaldi, L.A.; Li, X.S. Economic Measures of Pollination Services: Shortcomings and Future Directions. Trends Ecol. Evol. 2016, 31, 927-939. [CrossRef]

17. Foley, J.A.; DeFries, R.; Asner, G.P.; Barford, C.; Bonan, G.; Carpenter, S.R.; Stuart Chapin, F.; Coe, M.T.; Daily, G.C.; Gibbs, H.K.; et al. R EVIEW Global Consequences of Land Use. Science 2005, 309, 570-574. [CrossRef]

18. Quintas-Soriano, C.; Castro, A.J.; Castro, H.; García-Llorente, M. Impacts of Land Use Change on Ecosystem Services and Implications for Human Well-Being in Spanish Drylands. Land Use Policy 2016, 54, 534-548. [CrossRef]

19. Power, A.G. Ecosystem Services and Agriculture: Tradeoffs and Synergies. Philos. Trans. R. Soc. B Boil. Sci. 2010, 365, 2959-2971. [CrossRef]

20. Hauck, J.; Görg, C.; Varjopuro, R.; Ratamäki, O.; Jax, K. Benefits and limitations of the ecosystem services concept in environmental policy and decision making: Some stakeholder perspectives. Environ. Sci. Policy 2013, 25, 13-21. [CrossRef] 
21. Martín-López, B.; Montes, C.; Benayas, J. Influence of User Characteristics on Valuation of Ecosystem Services in Doñana Natural Protected Area (South-West Spain). Environ. Conserv. 2007, 34, 215-224. [CrossRef]

22. Amorim-Filho, O.B. Os Estudos da Percepção Como a Última Fronteira da Gestão Ambiental; Simpósio Situação Ambiental e Qualidade de Vida na Região Metropolitana de Belo Horizonte e Minas Gerais: Belo Horizonte, Brazil, 2002; Volume 2, pp. 16-20.

23. Tuan, Y.-F. Topofilia: Um Estudo da Percepção, Atitude e Valores do Meio Ambiente; Eduel: Londrina, Brazil, 2012.

24. Panquestor, E.K.; Riguetti, N.K. Percepção Ambiental, Descaso e Conservação: Uso Da Geoinformação No Estudo de Áreas Verdes Públicas Em Carangola-MG; IV Encontro Nacional da Anppas: Brasília, Brazil, 2008.

25. Racevskis, L.A.; Lupi, F. Comparing Urban and Rural Perceptions of and Familiarity with the Management of Forest Ecosystems. Soc. Nat. Resour. 2006, 19, 479-495. [CrossRef]

26. Ban, N.C.; Mills, M.; Tam, J.; Hicks, C.C.; Klain, S.; Stoeckl, N.; Bottrill, M.C.; Levine, J.; Pressey, R.L.; Satterfield, T.; et al. A Social-Ecological Approach to Conservation Planning: Embedding Social Considerations. Front. Ecol. Environ. 2013, 11, 194-202. [CrossRef]

27. Alassaf, A.; Alhunaiti, D.; Dick, J.; Al-Adwan, T. Differences in Perceptions, Attitudes, and Use of Ecosystem Services among Diverse Communities in an Arid Region: A Case Study from the South of Jordan. J. Hum. Ecol. 2014, 45, 157-165. [CrossRef]

28. Scholte, S.S.K.; van Teeffelen, A.J.A.; Verburg, P.H. Integrating Socio-Cultural Perspectives into Ecosystem Service Valuation: A Review of Concepts and Methods. Ecol. Econ. 2015, 114, 67-78. [CrossRef]

29. Vasco, A.; Zakrzevski, S. O Estado da Arte das Pesquisas sobre Percepção Ambiental no Brasil. Rev. Perspect. 2010, 34, 17-29.

30. Dias, O.A.; Mota, N.D. Percepção ambiental em comunidades rurais circundantes a um Reserva Particular do Patrimônio Natural. Rev. Eletrôn. Gest. Educa. Tecnol. Ambient. 2015, 19, 1153-1161.

31. de Santana, A.; Salomão, R.P.; Santana, A.L.; Castilho, A.F.; Gomes, S.C. O valor econômico da savana metalófita da Floresta Nacional de Carajás, estado do Pará: Uma contribuição teórica e metodológica. Rev. Teoria Evid. Econ. 2017, 23, 9-38. [CrossRef]

32. Lovejoy, T.E.; Nobre, C. Amazon tipping point: Last chance for action. Sci. Adv. 2019, 5, eaba2949. [CrossRef]

33. Fox, M. Amazon in flames (Interview). NACLA Rep. Am. 2019, 51, 328-332. [CrossRef]

34. Cordoba, D.; Juen, L.; Selfa, T.; Peredo, A.M.; Montag, L.F.A.; Sombra, D.; Santos, M.P.D. Forest Policy and Economics Understanding local perceptions of the impacts of large-scale oil palm plantations on ecosystem services in the Brazilian Amazon. For. Policy Econ. 2019, 109, 102007. [CrossRef]

35. Mul, M.; Pettinotti, L.; Amonoo, N.A.; Bekoe-Obeng, E.; Obuobie, E. Dependence of riparian communities on ecosystem services in Northern Ghana. IWMI Work. Pap. 2017, 179, 48.

36. Rojas, O.; Zamorano, M.; Saez, K.; Rojas, C.; Vega, C.; Arriagada, L.; Basnou, C. Social Perception of Ecosystem Services in a Coastal Wetland Post-Earthquake: A Case Study in Chile. Sustainability 2017, 9, 1983. [CrossRef]

37. Maestre-Andrés, S.; Calvet-Mir, L.; van den Bergh, J.C.J.M. Sociocultural valuation of ecosystem services to improve protected area management: A multi-method approach applied to Catalonia, Spain. Reg. Environ. Chang. 2015, 16, 717-731. [CrossRef]

38. Silva, O.M.A.; Homma, A.K. Pan-Amazônia: Visão Histórica, Perspectivas de Integração e Crescimento; FIEAM: Manaus, Brazil, 2015; p. 519.

39. Villela, R.; Bueno, R.S. A Expansão Do Desmatamento No Estado do Pará: População, Dinâmicas Territoriais e Escalas de Análise; XX Encontro Nacional de Estudos Populacionais: Foz do Iguaçu, Brazil, 2016.

40. IBGE. Instituto Brasileiro de Geografia e Estatística. Cidades: Parauapebas-PA. Available online: https: //cidades.ibge.gov.br/brasil/pa/parauapebas/panorama (accessed on 12 October 2018).

41. Cristo, L.A. Vulnerabilidade de Comunidades no Entorno de Ferrovias: O Caso do Ramal Ferroviário do Sudeste do Pará. Dissertação de Mestrado, Instituto Tecnológico Vale, Belém, Brazil, 2016.

42. Gómez-Baggethun, E.; Martín-Lopez, B.; Barton, D.; Braat, L.; Saarikoski, H.; Kelemen, E.; García-Llorente, M.; van den Bergh, J.; Arias, P.; Berry, P.; et al. State-of-the-Art Report on Integrated Valuation of Ecosystem Services. Eur. Comm. FP7 2014, 4, 1-33.

43. Van Riper, C.J.; Landon, A.C.; Kidd, S.; Bitterman, P.; Fitzgerard, L.A.; Granek, E.F.; Ibarra, S.; Iwaniec, D.; Raymond, C.M.; Toledo, D. Incorporating Sociocultural Phenomena into Ecosystem-Service Valuation: The Importance of Critical Pluralism. BioScience 2017, 67, 233-244. [CrossRef]

44. Melo, A.C.C.; Cardoso, A.C.D. O Papel Da Grande Mineração e Sua Interação Com a Dinâmica Urbana Em Uma Região de Fronteira Na Amazônia. Nova Econ. 2016, 26, 1211-1243. [CrossRef] 
45. INPE. Instituto Nacional de Pesquisas Espaciais. Projeto de Monitoramento da Floresta Amazônica por Satélite, Gráfico de Desflorestamento. Available online: http://www.dpi.inpe.br/prodesdigital/ prodesmunicipal.php (accessed on 15 December 2018).

46. Souza-Filho, P.W.M.; de Souza, E.B.; Silva Júnior, R.O.; Nascimento, W.R.; Versiani de Mendonça, B.R.; Guimarães, J.T.F.; Dall'Agnol, R.; Siqueira, J.O. Four Decades of Land-Cover, Land-Use and Hydroclimatology Changes in the Itacaiúnas River Watershed, Southeastern Amazon. J. Environ. Manag. 2016, 167, 175-184. [CrossRef]

47. Vale. Code of Ethical Conduct. 2013. Available online: http://www.vale.com/SiteCollectionDocuments/ CodigoEtica/assets/docs/EN_CodigoCondutaEtica_VF.pdf (accessed on 1 September 2020).

48. ILO. International Labour Organization. International Standard Classification of Occupations: ISCO 08, 2012. Geneva. Available online: http://www.ilo.org/public/english/bureau/stat/isco/index.htm (accessed on 1 September 2020).

49. IBGE. Instituto Brasileiro de Geografia e Estatística. Cidades: Pesquisa Nacional por Amostra de Domicílios (PNAD) 2015. Brasília, Brasil. Available online: https://sidra.ibge.gov.br/pesquisa/pnad (accessed on 16 November 2018).

50. R Core Team. R: A Language and Environment for Statistical Computing; R Foundation for Statistical Computing: Viena, Austria, 2019; Available online: https://www.R-project.org/ (accessed on 1 September 2020).

51. Blicharska, M.; Smithers, R.J.; Mikusiński, G.; Rönnbäck, P.; Harrison, P.A.; Nilsson, M.; Sutherland, W.J. Biodiversity's contributions to sustainable development. Nat. Sustain. 2019, 2, 1083-1093. [CrossRef]

52. Hartel, T.; Fischer, J.; Câmpeanu, C.; Milcu, A.I.; Hanspach, J.; Fazey, I. The Importance of Ecosystem Services for Rural Inhabitants in a Changing Cultural Landscape in Romania. Ecol. Soc. 2014, 19. [CrossRef]

53. Santos, A.M.; Mitja, D. Agricultura familiar e desenvolvimento local: Os desafios para a sustentabilidade econômico-ecológica na comunidade de Palmares II, Parauapebas, PA. Interações 2012, 13, 39-48. [CrossRef]

54. Schwartzman, S.; Alencar, A.; Zarin, H.; Santos Souza, A.P. Social Movements and Large-Scale Tropical Forest Protection on the Amazon Frontier: Conservation from Chaos. J. Environ. Dev. 2010, 19, 274-299. [CrossRef]

55. Piekielek, J. Cooperativism and Agroforestry in the Eastern Amazon: The Case of Tomé-Açu. Lat. Am. Perspect. 2010, 37, 12-29. [CrossRef]

56. Caldeira, C.F.; Giannini, T.C.; Ramos, S.J.; Vasconcelos, S.; Mitre, S.K.; Pires, J.P.A.; Ferreira, G.C.; Ohashi, S.; Mota, J.A.; Castilho, A.; et al. Sustainability of Jaborandi in the eastern Brazilian Amazon. Perspect. Ecol. Conserv. 2017, 15, 161-171. [CrossRef]

57. Porro, R.; Miller, R.P.; Tito, M.R.; Donovan, J.A.; Vivan, J.L.; Trancoso, R.; Van Kanten, R.F.; Grijalva, J.E.; Ramirez, B.L.; Gonçalves, A.L. Agroforestry in the Amazon Region: A Pathway for Balancing Conservation and Development. In Agroforestry - The Future of a Global Land Use; Nair, P., Garrity, D., Eds.; Springer: Dordrecht, The Netherlands, 2012; Volume 9, pp. 391-428. [CrossRef]

58. da Cruz, D.C.; Benayas, J.M.R.; Ferreira, G.C.; Santos, S.R.; Schwartz, G. An overview of forest loss and restoration in the Brazilian Amazon. N. For. 2020, 1-16. [CrossRef]

59. Peralta, N. Ecotourism as an Incentive to Biodiversity Conservation: The Case of Uakari Lodge, Amazonas, Brazil. Sci. Mag. UAKARI 2013, 8, 75-93. [CrossRef]

60. Strand, J.; Soares-Filho, B.; Costa, M.H.; Oliveira, U.; Ribeiro, S.C.; Pires, G.F.; Oliveira, A.; Rajão, R.; May, P.; van der Hoff, R.; et al. Spatially explicit valuation of the Brazilian Amazon Forest's Ecosystem Services. Nat. Sustain. 2018, 1, 657-664. [CrossRef]

61. Droste, N.; D'Amato, D.; Goddard, J.J. Where communities intermingle, diversity grows-The evolution of topics in ecosystem service research. PLoS ONE 2018, 13, e0204749. [CrossRef]

62. Arvor, D.; Daugeard, M.; Tritsch, I.; Mello-Thery, N.A.; Thery, H.; Dubreuil, V. Combining socioeconomic development with environmental governance in the Brazilian Amazon: The Mato Grosso agricultural frontier at a tipping point. Environ. Dev. Sustain. 2016, 20, 1-22. [CrossRef]

63. Sathler, D.; Adamo, S.B.; Lima, E.E.C. Deforestation and local sustainable development in Brazilian Legal Amazonia: An exploratory analysis. Ecol. Soc. 2018, 23, 30. [CrossRef] 
64. Tritsch, I.; Arvor, D. Transition in environmental governance in the Brazilian Amazon: Emergence of a new pattern of socio-economic development and deforestation. Land Use Policy 2016, 59, 446-455. [CrossRef]

65. Song, M.; Huntsinger, L.; Han, M. How Does the Ecological Well-Being of Urban and Rural Residents Change with Rural-Urban Land Conversion? The Case of Hubei, China. Sustainability (Switzerland) 2018, 10, 527. [CrossRef]

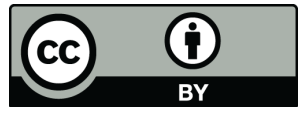

(C) 2020 by the authors. Licensee MDPI, Basel, Switzerland. This article is an open access article distributed under the terms and conditions of the Creative Commons Attribution (CC BY) license (http://creativecommons.org/licenses/by/4.0/). 